\title{
Interferon-beta changes the expression of IL10, IL23A and FOXP3 on Multiple Sclerosis patients' T cells
}

\author{
Hazal Gezmis ${ }^{1}$, Tansu Doran ${ }^{1}$, Saime Fusun Mayda Domac ${ }^{2}$, Deniz Yucel $^{3}$, Rahsan \\ Karaci $^{2}$, and Deniz Yat ${ }^{4}$ \\ ${ }^{1}$ Yeditepe University \\ ${ }^{2}$ İstanbul Erenköy Ruh ve Sinir Hastalıkları Egitim ve Arastirma Hastanesi \\ ${ }^{3}$ Acibadem Universitesi \\ ${ }^{4}$ Yeditepe Universitesi
}

January 16, 2021

\begin{abstract}
Aim of the Study: Multiple sclerosis (MS) is an autoimmune disorder causing demyelination in axons. Available therapies target different molecules, but not all have therapeutic effects on disease progression, and this effect can only be seen after a longtime administration. Interferon beta (IFN- $\beta$ ), an MS therapy for many years, slows down the disease progression and reduces disease symptoms by targeting $\mathrm{T}$ cells. Yet, a considerable portion of the patient has experienced no therapeutic response to IFN- $\beta$. It is necessary to determine disease-specific biomarkers which allow early diagnosis or treatment of MS. Here, it was aimed to determine the effects of interleukin 10 (IL10) and 23 (IL23A) as well as forkhead box P3 (FOXP3) genes on MS after IFN- $\beta$ therapy. Materials \& Methods: Peripheral blood mononuclear cells (PBMCs) were extracted to isolate CD4+ and CD25+ T cells. Cytotoxicity assays were performed on each cell type for determining optimum drug concentration. Then, cells were cultured and determined drug concentration was administered to the cells to measure gene expressions with RT-PCR. Results: It was found that the cytotoxic effect of IFN- $\beta$ was more efficient as the exposure time was expanded regardless of drug concentration. Moreover, CD25+ T lymphocytes were more resistant to IFN- $\beta$. IL23A was down-regulated, whereas FOXP3 was up-regulated at $48 \mathrm{~h}$ in CD4+ T cells. For CD25+ T cells, the graded increase of FOXP3 was obtained while IL10 expression was gradually decreased throughout the drug intake, significantly. Conclusion: Although considerable change in expression was obtained, the long-term IFN- $\beta$ effect on both genes and cells should be determined by follow-up at least a year. Keywords: MS, IFN- $\beta$, IL23A, FOXP3, IL10, T cells
\end{abstract}

\section{Hosted file}

Hazal Gezmis_The International Journal of Clinical Practice.pdf available at https: //authorea.com/users/350734/articles/504312-interferon-beta-changes-the-expression-ofil10-il23a-and-foxp3-on-multiple-sclerosis-patients-t-cells

\section{Hosted file}

Hazal Gezmis_The International Journal of Clinical Practice.pdf available at https: //authorea.com/users/350734/articles/504312-interferon-beta-changes-the-expression-ofil10-il23a-and-foxp3-on-multiple-sclerosis-patients-t-cells 
Interferon-beta changes the expression of IL10, IL23A and FOXP3 on Multiple Sclerosis patients' $T$ cells

Short Title: Interferon-beta changes gene expression on $\mathrm{T}$ cells

${ }^{* *}$ Hazal Gezmis ${ }^{\mathrm{a}{ }^{*}},{ }^{* *}$ Tansu Doran ${ }^{\mathrm{a}}$, Fusun Domac Mayda ${ }^{\mathrm{b}}$, Deniz Yucel ${ }^{\mathrm{c}}$, Rahsan Oz ${ }^{\mathrm{b}}$, Deniz $\mathrm{Kirac}^{\mathrm{a}}$

${ }^{a}$ Department of Medical Biology, Faculty of Medicine, Yeditepe University, 34755, Istanbul, Turkey;

${ }^{b}$ Department of Neurology, Erenkoy Mental and Nervous Diseases Training and Research Hospital, 34736, Istanbul, Turkey;

'Department of Histology and Embryology, Faculty of Medicine, Acibadem Mehmet Ali Aydinlar University, 34684, Istanbul, Turkey.

*Correspondence: hazalgezmis@gmail.com (Hazal Gezmis)

**These authors contributed equally to this work.

\section{Acknowledgements}

Hazal Gezmis and Tansu Doran performed the experiments and wrote this paper. Dr Deniz Kirac and Hazal Gezmis designed the study. Dr Fusun Domac Mayda determined the eligibility of MS patients and collected the blood samples. Dr Rahsan Oz contributed to writing this paper. Dr Deniz Yucel collaborated on in vitro study design and the evaluation of the results. This work was supported by the Scientific and Technological Research Council of Turkey (TÜBİTAK) [SBAG-216S828]. We are grateful to Dr Gamze Torun Kose for their support on study design, Dr Omer Faruk Bayrak and Emre Can Tuysuz for performing FACS.

Present address: Department of Materials, University of Oxford, OX1 3PH, Oxfordshire, United Kingdom 
Tables
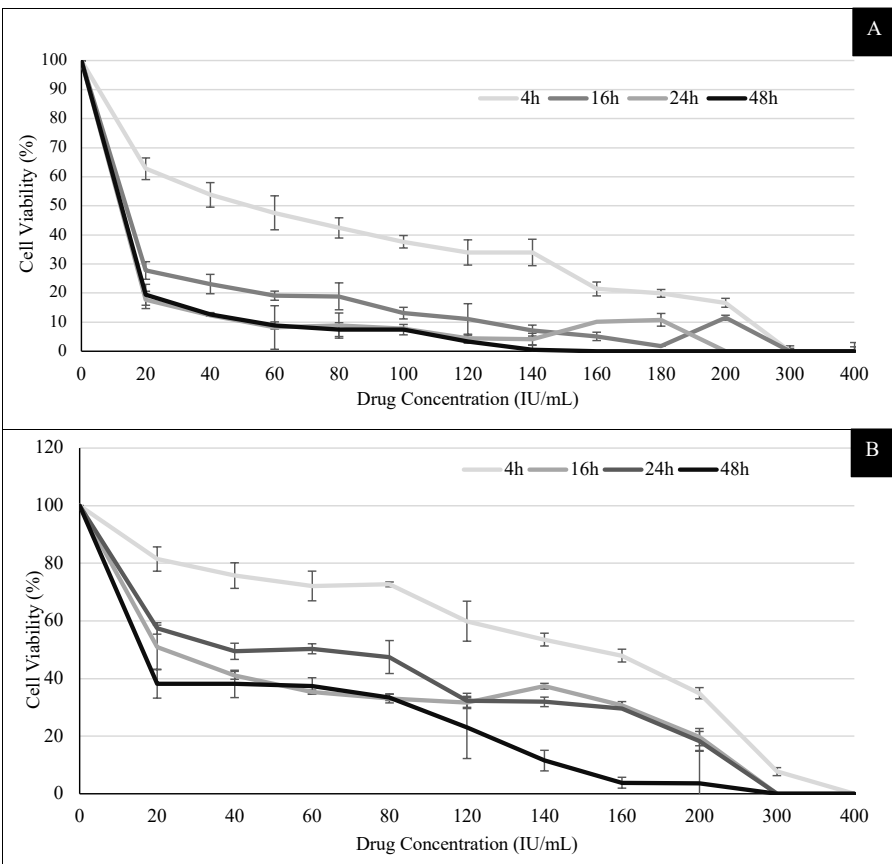

Table 1. Cytotoxicity assay results. WST-1 assay determined cytotoxicity profile of IFN- $\beta$ after $4,16,24$ and $48 \mathrm{~h}$ incubation with a) CD4 $+\mathrm{T}$ cells and b) $\mathrm{CD} 25+\mathrm{T}$ cells at varied concentrations $(\mathrm{n}=3)$ 


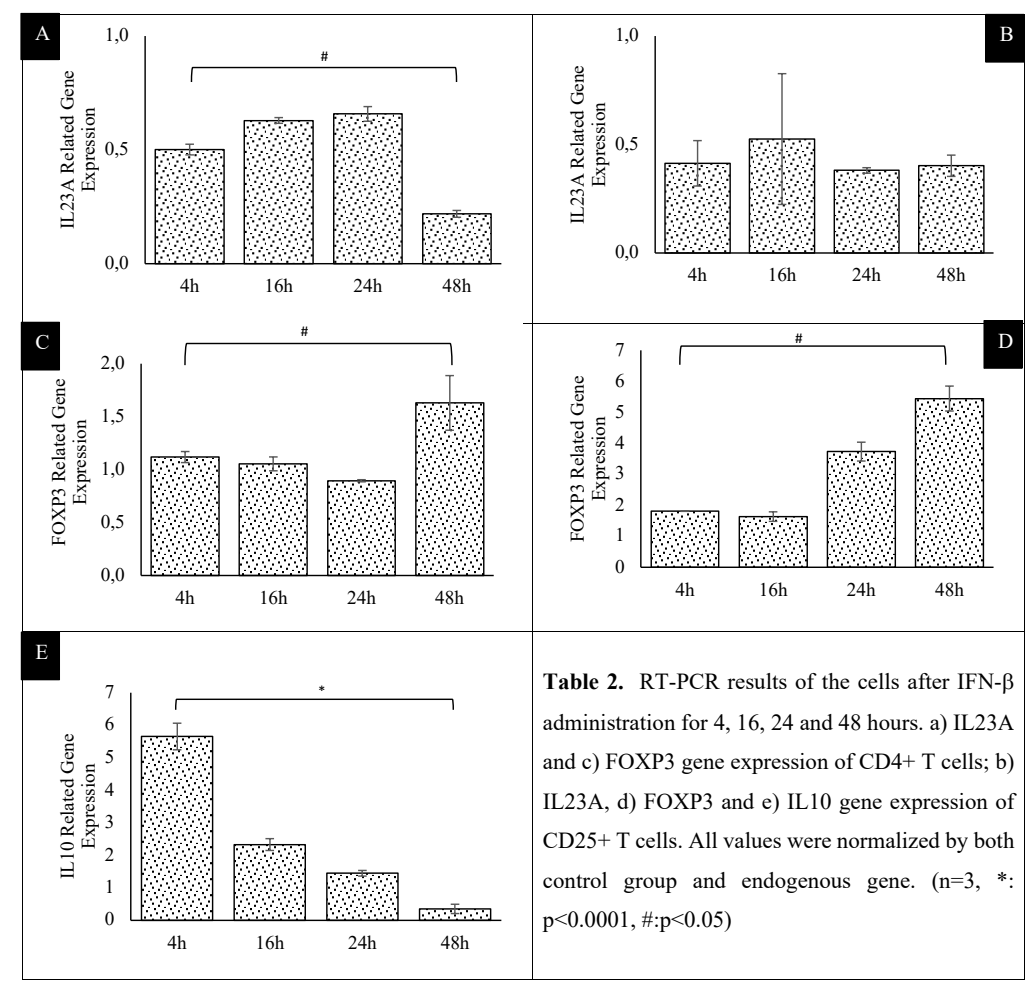




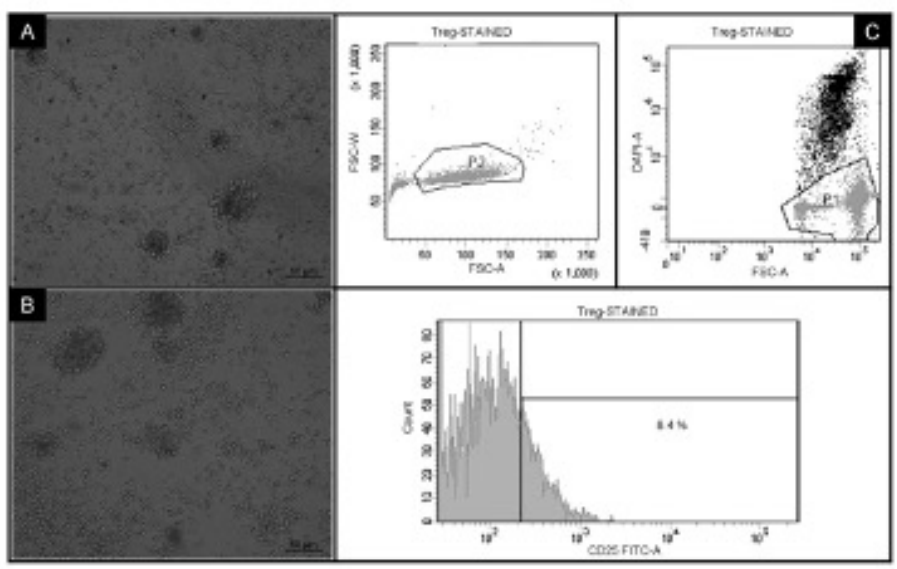

